\author{
В.Й. Климченко ${ }^{1}$, Д.А. Дончак ${ }^{2}$, М.М. Донченко ${ }^{2}$ В.О. Тютюнник ${ }^{1}$ \\ ${ }^{1}$ Харківський національний університет Повітряних Сил ім. І. Кожедуба, Харків \\ ${ }^{2}$ Командування Повітряних Сил Збройних Сил Украӥни, Вінниия
}

\title{
ПРОБЛЕМИ НАБУТТЯ СПРОМОЖНОСТЕЙ РАДІОТЕХНІЧНИХ ВІЙСЬК З РОЗВІДКИ ПЕРСПЕКТИВНИХ ЗАСОБІВ ПОВІТРЯНОГО НАПАДУ
}

\begin{abstract}
Показано, щяо існуюча система радіолокаційної розвідки повітряного простору, фізичну основу якої становить двоярусне радіолокаиійне поле, неспроможна з об'єктивних причин здійснювати своєчасне виявлення і неперервне супроводження таких перспективних засобів повітряного нападу, як малорозмірні безпілотні літальні апарати тактичного призначення та гіперзвукові крилаті ракети.

Проаналізовані особливості радіолокаціийної розвідки малорозмірних безпілотних літальних апаратів тактичного призначення та гіперзвукових крилатих ракет підрозділами радіотехнічних військ.

Визначені шляхи і напрямки набуття спроможностей радіотехнічних військ щуодо вчасного виявлення $i$ неперервного супроводження означених типів літальних апаратів.
\end{abstract}

Ключові слова: радіолокаційне поле, малорозмірні безпілотні літальні апарати тактичного призначення, гіперзвукові крилаті ракети, виявлення, супроводження.

\section{Вступ}

Постановка проблеми. Мета охорони повітряного простору досягається шляхом виконання низки завдань, зокрема, ведення розвідки повітряного простору з метою виявлення повітряного нападу, загроз порушень та порушень державного кордону України. Для вирішення цього завдання застосовуються радіолокаційні засоби, які знаходяться на озброєнні радіотехнічних військ (РТВ) Повітряних Сил Збройних Сил України та виконують функції виявлення та визначення координат повітряних об'єктів в усьому діапазоні їх висот та швидкостей польоту в безперешкодовій обстановці та в умовах впливу навмисних і ненавмисних активних і пасивних перешкод [1]. Від ефективності функціонування системи розвідки повітряного противника, зокрема системи радіолокаційної розвідки, залежить успішність виконання завдань охорони повітряного простору, протиповітряної оборони (ППО) та оперативного застосування Повітряних Сил [2].

Система радіолокаційної розвідки повітряного противника та радіолокаційні засоби, які іiї утворюють, розвиваються у відповідності з розвитком засобів повітряного нападу (ЗПН).

На теперішній час спостерігається поява та розвиток нових типів ЗПН:

- малорозмірні безпілотні літальні апарати (міні-БпЛА), які набувають широкого застосування в локальних воєнних конфліктах [3];

- гіперзвукові літальні апарати (ГЗЛА), які будуть діяти переважно в білякосмічному просторі [4-5].

Проблемні питання щодо виявлення і супроводження нових типів ЗПН та визначення шляхів i напрямків розвитку радіолокаційної системи для їх вирішення є актуальними.

Аналіз останніх досліджень і публікацій. Ефективність застосування БпЛА в якості ЗПН переконливо підтверджена в багатьох локальних збройних конфліктах. БПЛА використовуються в арміях провідних країн світу для виконання широкого кола бойових завдань [6]. За масштабом використання найбільш поширеними $є$ малорозмірні БпЛА тактичного призначення [7], які стали ефективним засобом вирішення завдань тактичної розвідки, радіоелектронної боротьби, наведення різних платформ зброї та безпосереднього нанесення ударів по наземних цілях (ударні БпЛА, баражуючі боєприпаси та ін.) [3]. Такі типи БпЛА є найбільш проблемними щодо їх своєчасного виявлення та протидії. Пошук ефективних способів та засобів боротьби з такими БПЛА останнім часом відбувається досить активно.

Для виявлення БПЛА можуть використовуватись різноманітні фізичні явища, які супроводжують політ БпЛА, як матеріального об'єкту, і демаскують його в середовищі перебування. На основі цих явищ активно розробляються різноманітні засоби своєчасного виявлення БПЛА. Найбільш поширеними $є$ радіолокаційні станції (РЛС) та засоби радіотехнічної розвідки [8-9]. Використовують також акустичні [10], оптико-електронні засоби та засоби розвідки в інфрачервоному діапазоні [11]. Водночас, кожен 3 означених засобів окремо не може бути універсальним засобом виявлення малорозмірних БПЛА через слабкість супроводжуючих їх явищ. Завдання виявлення БпЛА найбільш ефективно може бути вирішено через системне поєднання усіх можливих засобів, як це пропонується в [12].

На сьогодні у військах відсутні універсальні за- 
соби виявлення та супроводження БпЛА, тому ця проблема стоїть досить гостро. Використання для іï вирішення потужних РЛС є малоефективним з багатьох причин [13].

Черговим викликом для існуючих систем ППО є розвиток нового типу ЗПН, які здійснюють політ на швидкостях більше 5М у верхніх шарах атмосфери [4; 14]. Найбільшого розвитку отримали гіперзвукові крилаті ракети. В Російській Федерації розробка гіперзвукових крилатих ракет вийшла на завершальний етап [5]. Деякі з них уже прийняті на озброєння. Прикладом може бути гіперзвуковий авіаційний ракетний комплекс “Кинжал" з ракетою X-47M2, яким оснащується літак МиГ-31К. Розробка аналогічних ЗПН здійснюється в США, Китаї, Індії та інших провідних країнах світу [14-15]. Масове надходження на озброєння означених ЗПН в арміях провідних країн слід очікувати в найближчі $5 \ldots 7$ років.

Метою цієї статті є оцінка існуючих спроможностей РТВ з виявлення і супроводження БпЛА тактичного призначення і ГЗЛА та визначення шляхів і напрямків розвитку радіолокаційної системи, здатної вчасно виявляти і безперервно супроводжувати означені типи літальних апаратів.

\section{Виклад основного матеріалу}

1. Загальна характеристика можливостей існуючої радіолокачійної системи з розвідки ЗПН.

Фізичну основу існуючої системи радіолокаційної розвідки ЗПН становить двоярусне радіолокаційне поле (РЛП), яке покриває всю територію держави та прилеглі райони суміжних держав на глибину 200...300 км (рис. 1).

Нижній ярус РЛП до висот 4...6 км створюється РЛС радіолокаційних рот (рлр), які мають на озброєнні маловисотні РЛС типу 35Д6М, 35Д6, $19 Ж 6$ та ін. Верхній ярус поля до висот $25 \ldots 30$ км створюється більш потужними РЛС типу 79К6, П37, 5H84А, П-18 “Малахіт” та ін., які перебувають на озброєнні радіотехнічних батальйонів (ртб).

Нижня межа суцільного РЛП становить $300 \ldots 500$ м. Коефіцієнт перекриття РЛП на середніх і великих висотах становить 1,5...3.

РЛП нижче 300 м створюється за потребою в окремих районах маловисотними радіолокаційними взводами.

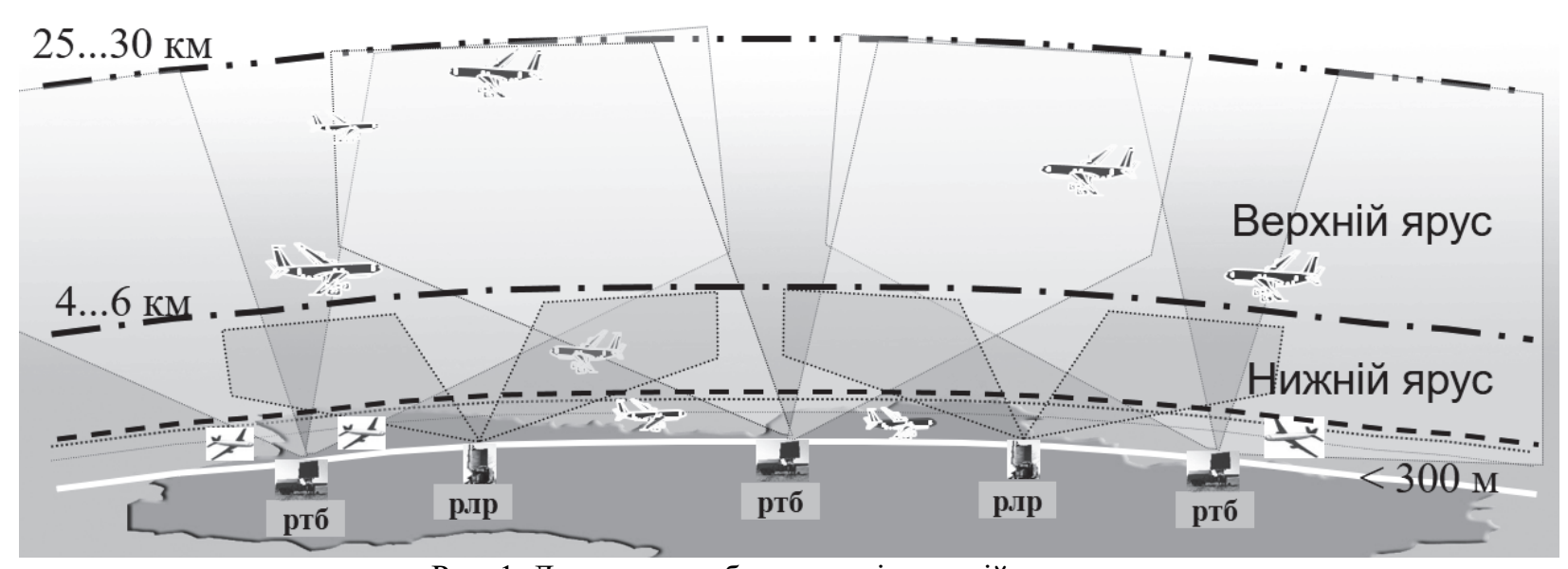

Рис. 1. Двоярусна побудова радіолокаційного поля Джерело: розроблено авторами.

Означена структура РЛП тривалий час відповідала вимогам щодо своєчасного виявлення та безперервного супроводження існуючих ЗПН. Будь-які ЗПН, які перебувають в зазначених межах простору і рухаються зі швидкістю не менше $10 \mathrm{~m} / \mathrm{c}$ і не більше 1500 м/с, будуть своєчасно виявлені і взяті на супроводження. В означену просторово-швидкісну зону (рис. 2) попадають усі традиційні засоби стратегічної (СА), тактичної (ТА), армійської (АА), транспортної авіації (ТрА), крилаті ракети (КР), тощо. Власне для виявлення та супроводження саме таких ЗПН створювалась та розвивалась система.

Поява на озброєнні армій провідних країн світу нових типів ЗПН, як БпЛА та ГЗЛА поставила перед РТВ такі задачі, які об'єктивно неможливо вирішити без розробки спеціальних РЛС та зміни самих принципів побудови усієї системи.

Об'єктивність полягає в тому, що просторовошвидкісна область дії нових ЗПН або повністю виходить за межі дії існуючої радіолокаційної системи, або перекривається лише частково (рис. 2).

2. Особливості радіолокаційної розвідки БпЛА підрозділами РТВ.

Масове використання БпЛА в локальних конфліктах поставило перед системами ППО нові завдання щодо їх своєчасного виявлення і протидії.

Поняття БПЛА охоплює широкий клас літальних апаратів від мініатюрних розвідувальних дронів (БПЛА поля бою) до БПЛА стратегічного призначення. 


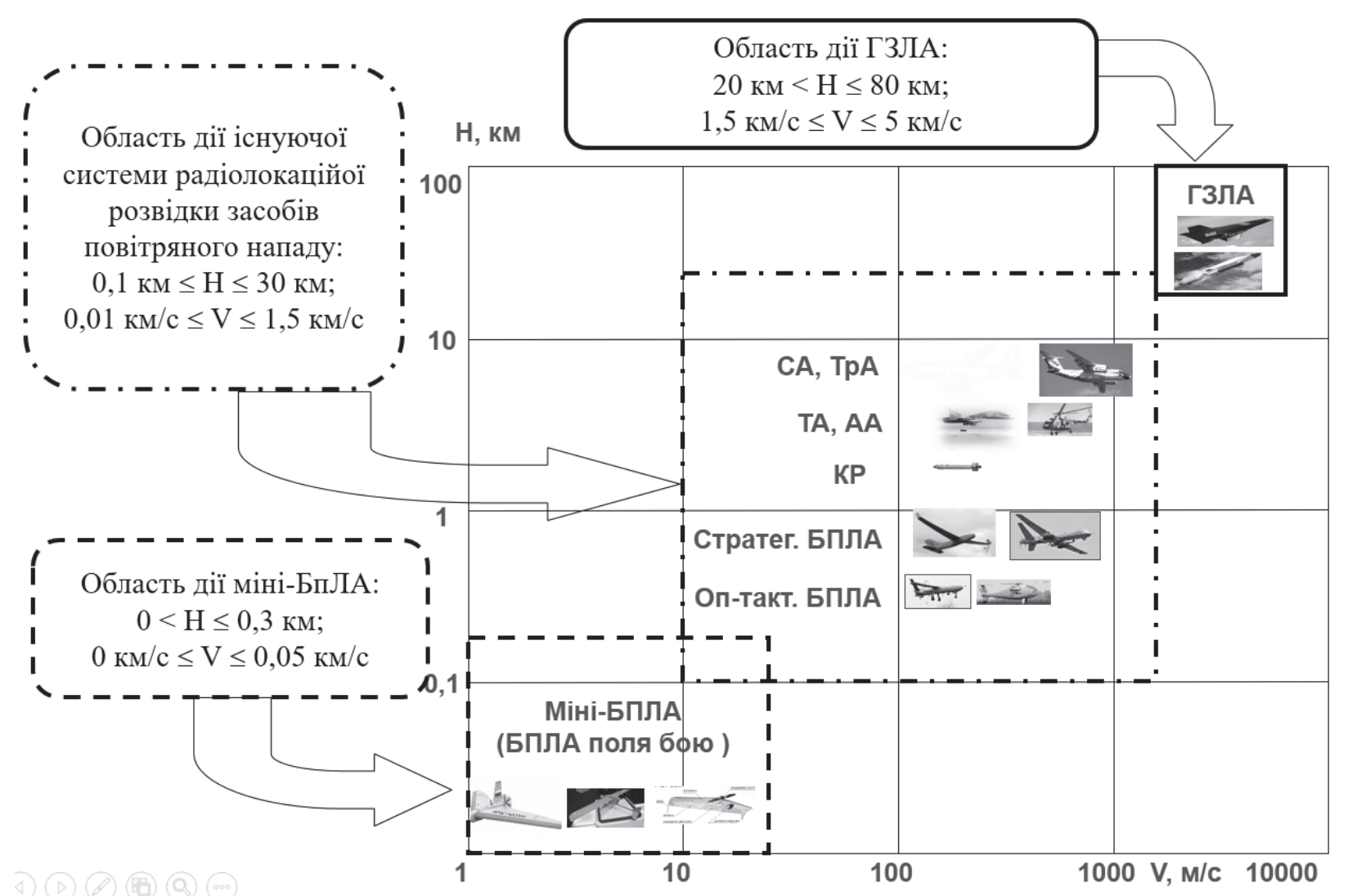

Рис. 2. Спроможності існуючої системи радіолокаційної розвідки засобів повітряного нападу Джерело: розроблено авторами.

БпЛА стратегічного і оперативно-тактичного призначення мало чим відрізняються від пілотованих літальних апаратів аналогічного призначення, $\mathrm{i}$ проблем з виявленням та супроводженням їх за допомогою існуючих РЛС не виникає. Інша справа 3 мініатюрними БПЛА поля бою, які останнім часом набули широкого поширення.

Енергетичного потенціалу РЛС РТВ (табл. 1) вистачає для того, щоб теоретично виявляти мініБпЛА на дальностях 15..20 км.

Практичні ж можливості фактично зводяться нанівець (рис. 3) через низку об'єктивних чинників:

- виявлення міні-БПЛА здійснюється в зоні дії віддзеркалень від місцевих предметів, радіус якої може становити $30 \ldots 40$ км, що вимагає застосування системи селекції рухомих цілей (СРЦ);

- система СРЦ має малу ефективність щодо міні-БпЛА через їх малу швидкість.

В [13] доведено, що сучасна РЛС типу П-18 "Малахіт", яка розташована від лінії контролю на відстані не менш 15 км, принципово не може виявляти міні-БПЛА, які ведуть розвідку в смузі $5 \ldots 7$ км, здійснюючи польоти вздовж лінії контролю. Аналогічна ситуація з виявленням міні-БПЛА є характерною і для інших оглядових РЛС РТВ. Певне виключення становлять рухомі радіовисотоміри (РPB) (рис. 3). Маючи високий енергетичний потен- ціал та ширину діаграми спрямованості антени у вертикальній площині $0,9^{\circ}$, вони можуть частково виявляти цілі типу міні-БПЛА поза зоною дії віддзеркалень від місцевих предметів.

Таблиця 1

Дальність виявлення міні- БПЛА

на малих та гранично малих висотах РЛС РТВ

\begin{tabular}{|c|c|c|c|c|}
\hline \multirow[t]{2}{*}{ Тип РЛС } & \multicolumn{4}{|c|}{$\begin{array}{l}\text { Дальність виявлення міні-БПЛА }\left(\sigma=0,001 \mathrm{~m}^{2}\right) \\
\text { РЛС РТВ [км] на висотах польоту БПЛА }\end{array}$} \\
\hline & $100 \mathrm{M}$ & $200 \mathrm{M}$ & $300 \mathrm{M}$ & $1000 \mathrm{M}$ \\
\hline $\begin{array}{c}19 Ж 6 \\
\text { (35Д6) }\end{array}$ & 22 & 25 & 25 & 25 \\
\hline $\begin{array}{c}\text { П-18 } \\
\text { "Малахіт" } \\
\end{array}$ & 10 & 14 & 21 & 28 \\
\hline $\begin{array}{c}5 \mathrm{H} 84 \mathrm{~A} \\
(5 \mathrm{H} 84 \mathrm{MA}) \\
\end{array}$ & 18 & 25 & 37 & 52 \\
\hline П-37 & 18 & 20 & 26 & 26 \\
\hline 79К6 & 28 & 36 & 40 & 50 \\
\hline $\begin{array}{c}\Pi-19 \\
(\Pi-19 \mathrm{MA})\end{array}$ & 12 & 18 & 13 & 17 \\
\hline ПРВ-13 & 30 & 45 & 50 & 50 \\
\hline ПРВ-16 & 30 & 35 & 35 & 35 \\
\hline ПРВ-17 & 36 & 48 & 60 & 60 \\
\hline
\end{tabular}

Джерело: розроблена авторами за даними [13, С. 92-98]. 
В цілому ж використання оглядових РЛС РТВ для виявлення тактичних міні-БпЛА є недоцільним i невиправданим. Недоцільним - через надзвичайно низькі можливості 3 виявлення означеного типу цілей, а невиправданим - через невідповідність масштабів задач, для вирішення яких розроблялись РЛС РТВ, і задач з виявлення міні-БПЛА.
Таким чином, для вирішення завдання з виявлення міні-БпЛА потрібні спеціалізовані РЛС з дальністю виявлення не більше 40 км і ефективною системою СРЦ по малошвидкісним цілям, що вимагає використання в РЛС високої частоти посилок зондувальних сигналів.
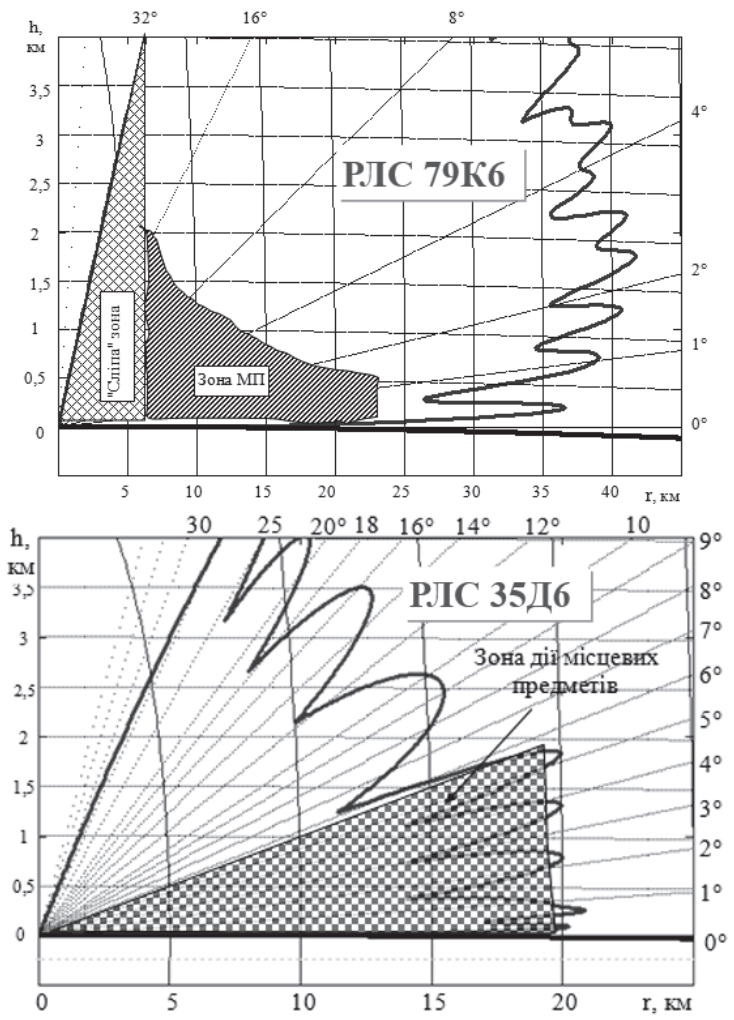
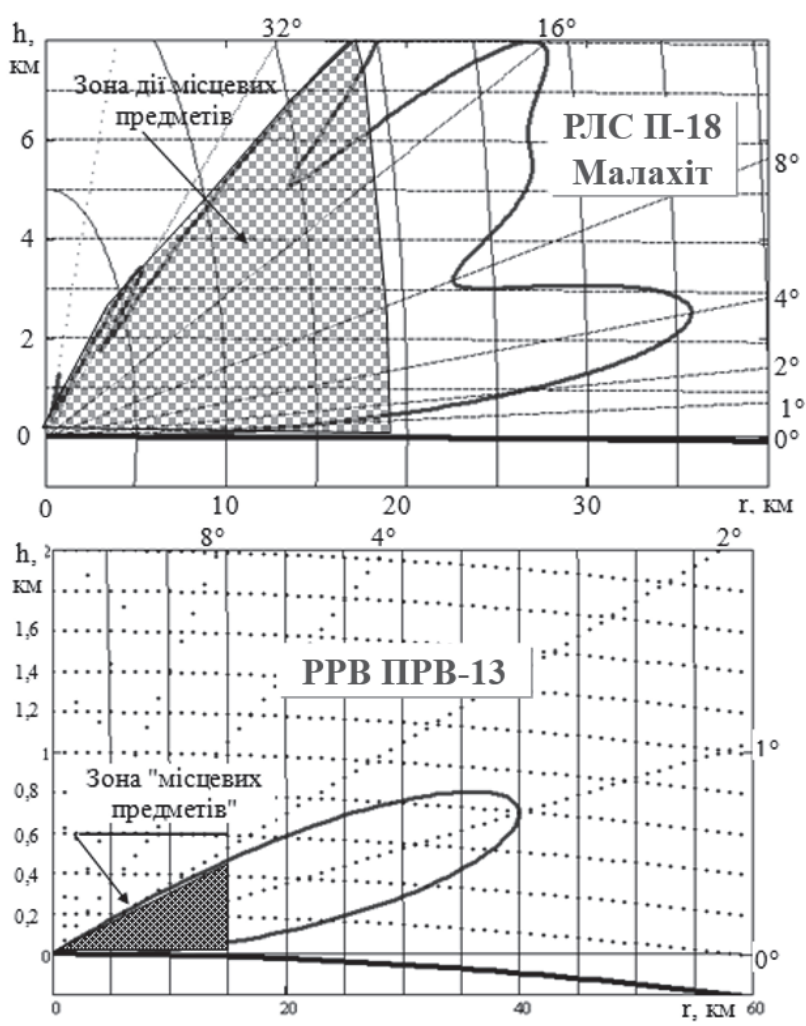

Рис. 3. Зони виявлення міні-БпЛА РЛС РЛС РТВ

Джерело: розроблено авторами з використанням [13, С. 92-98, рис. 8-10; 12].

В багатьох країнах світу та в Україні розробки таких РЛС активно проводяться. За їх допомогою можна оперативно створювати осередкові РЛП до висот $300 \ldots 500$ м з метою виявлення міні-БПЛА в районах розташування важливих об'єктів та особливих зонах.

3. Аналіз можливостей з радіолокаиійної розвідки та супроводження гіперзвукових аеродинамічних літальних апаратів.

Наступним викликом РТВ є забезпечення виявлення та супроводження ГЗЛА, які на сьогодні успішно розвиваються. ГЗЛА вважаються такі апарати, які здійснюють польоти за законами аеродинаміки зі швидкістю не менше, ніж 5М.

У теперішній час розвиток ГЗЛА здійснюється в трьох основних напрямках (рис. 4):

- розробка так званих глайдерів, тобто спеціальних бойових головок міжконтинентальних балістичних ракет (МБР), які відокремлюються від МБР на висотах $60 \ldots 80$ км і здійснюють самостійний планерний політ в розріджених шарах 3 вибором цілі в радіусі 200...300 км від точки балістичного прицілювання;

- розробка гіперзвукових крилатих ракет (ГЗКР), які доставляються в розріджені шари атмосфери або літаками, або ракетами і далі здійснюють тривалий самостійний маневрений політ до цілі на відстань в кілька сотень і навіть тисяч кілометрів;

- розробка гіперзвукових пілотованих літаків 3 дальністю польотів 10000...20000 км.

Найбільшого успіху досягнуто в напрямку ГЗКР, які активно розробляються багатьма країнами (Росія, Китай США, Індія) і будуть найближчим часом прийняті, а деякі з них уже прийняті на озброєння (“Кинжал”, “Циркон” - Росія).

Спільним для усіх типів ГЗЛА $є$ те, що вони здійснюють політ в розріджених шарах атмосфери на висотах 20..60 км зі швидкістю близько $10 \mathrm{M}$ (табл. 2). 


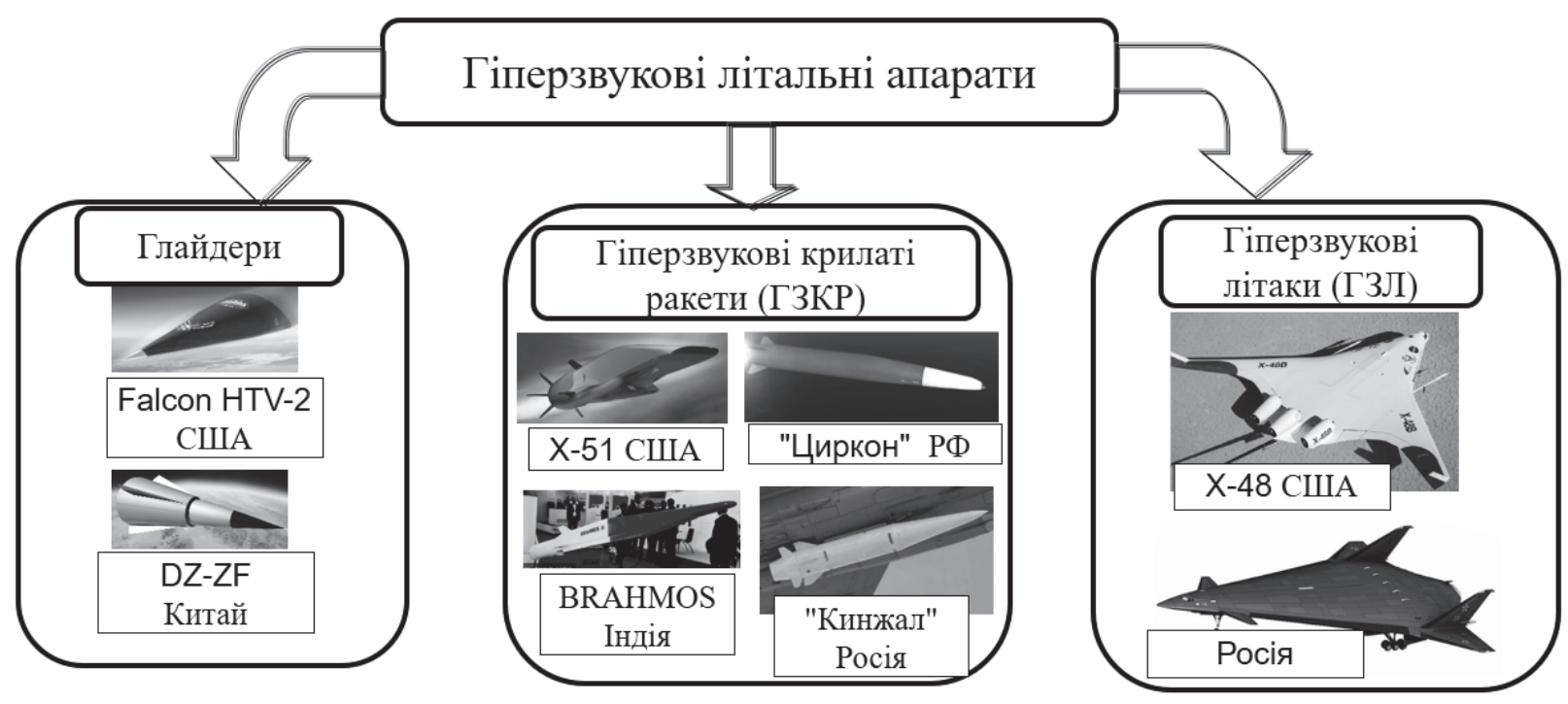

Рис. 4. Напрямки розвитку ГЗЛА

Джерело: розроблено авторами.

Таблиця 2

Основні льотно-технічні характеристики ГЗЛА

\begin{tabular}{|c|c|c|c|c|c|}
\hline $\begin{array}{c}\text { Тип } \\
\text { ГЗЛА }\end{array}$ & $\begin{array}{c}\text { Швидкість, } \\
\text { числа } \\
\text { Маха }\end{array}$ & $\begin{array}{c}\text { Висота } \\
\text { польоту, } \\
\text { км }\end{array}$ & $\begin{array}{c}\text { Даль- } \\
\text { ність } \\
\text { польо } \\
\text { ту, } \\
\text { км }\end{array}$ & $\begin{array}{c}\text { Наявність } \\
\text { двигуна }\end{array}$ & Носій \\
\hline $\begin{array}{c}\text { Глай- } \\
\text { дер }\end{array}$ & $(10 \ldots 20) \mathrm{M}$ & 80 & $\begin{array}{c}200 \ldots \\
300\end{array}$ & $\begin{array}{c}\text { Відсутній. } \\
\text { Політ пла- } \\
\text { неруваль- } \\
\text { ний }\end{array}$ & МБР \\
\hline ГЗКР & $(5 \ldots 10) \mathrm{M}$ & $20 \ldots 60$ & $\begin{array}{c}500 \ldots \\
1500\end{array}$ & $\begin{array}{c}\text { ППРД } \\
\text { ГЗЛ }\end{array}$ & $\begin{array}{c}\text { Кіта- } \\
\text { ОТР }\end{array}$ \\
\hline (5..10)М & $20 \ldots 40$ & $\begin{array}{c}12000 \\
\ldots\end{array}$ & $\begin{array}{c}\text { ППРД+ } \\
\text { ТРД }\end{array}$ & - \\
\hline
\end{tabular}

Джерело: [4, С. 79-85; 5, С. 63-69; 14; 15, С. 10-17].

Отже, в область дії існуючої радіолокаційної системи вони попадають лише частково за висотним параметром і зовсім виходять за межі за швидкісним параметром. Це означає, що разове виявлення таких цілей на висотах близько 30 км існуючими РЛС (5Н84А, 5Н84АМА) ще можливе, а супроводження - принципово неможливе через низький для таких цілей темп огляду простору. В тих країнах, які мають системи попередження про ракетний напад (СПРН), означене завдання може бути покладене на такі системи. Але оскільки в Україні СПРН відсутня, то вихід - в розробленні і прийнятті на озброєння спеціалізованих РЛС, здатних виявляти ГЗЛА типу ГЗКР на дальностях близько 1000 км і на висотах близько $60 \ldots 80$ км. Для супроводження ГЗКР в діапазоні швидкостей до $10 \mathrm{M}$ період оновлення інформації має становити не більше 2 с.
Такими РЛС мають оснащатися окремі підрозділи (радіотехнічні центри (ртц)) по одному на повітряне командування 3 видачею інформації безпосередньо на розвідувально-інформаційний центр. Для створення суцільного поля в кожному з таких підрозділів має бути по дві-три РЛС.

5. Нарощення спроможностей РТВ з розвідки перспективних засобів повітряно-космічного нападу.

Широке застосування БПЛА уже сьогодні i ГЗКР в найближчому майбутньому змушує переглянути принципи створення РЛП. Необхідно переходити від двоярусної побудови РЛП до чотириярусної (рис. 5) 3 чітким поділом відповідальності суб'єктів добування інформації про повітряну обстановку.

Нижній ярус по висоті (ярус гранично малих висот - ГМВ) має перекривати область дії мініБПЛА (200...300 м). Створити суцільним над усією територією країни РЛП на таких висотах практично неможливо і потреби в цьому немає. Його доцільно створювати спеціальними РЛС типу “Око" чи “Снов” осередково навколо важливих державних об'єктів (ВДО) та в особливих зонах. Відповідальність за виявлення і супроводження міні-БПЛА несуть ті суб'єкти, в чиїх інтересах створювались відповідні зони.

РЛП до висот 4...6 км (ярус малих і середніх висот - ярус МСВ, рис. 5) має бути суцільним i створюється за допомогою РЛС ртб, маловисотних рлр і окремих радіолокаційних взводів.

Ярус великих висот (ярус ВВ, рис. 5) створюється переважно за допомогою РЛС ртб і охоплює простір до висот 25...30 км, забезпечуючи виявлення i супроводження висотних цілей і статосферних цілей, які здійснюють політ в нижній частині стратосфери. 
Ярус стратосферних висот (ярус СВ, рис. 5) створюється спеціальними РЛС новоутворених радіотехнічних центрів, забезпечуючи виявлення i супроводження гіперзвукових літальних апаратів, які здійснюють політ у верхній частині стратосфери та у мезосфері до висот $60 \ldots 80$ км.

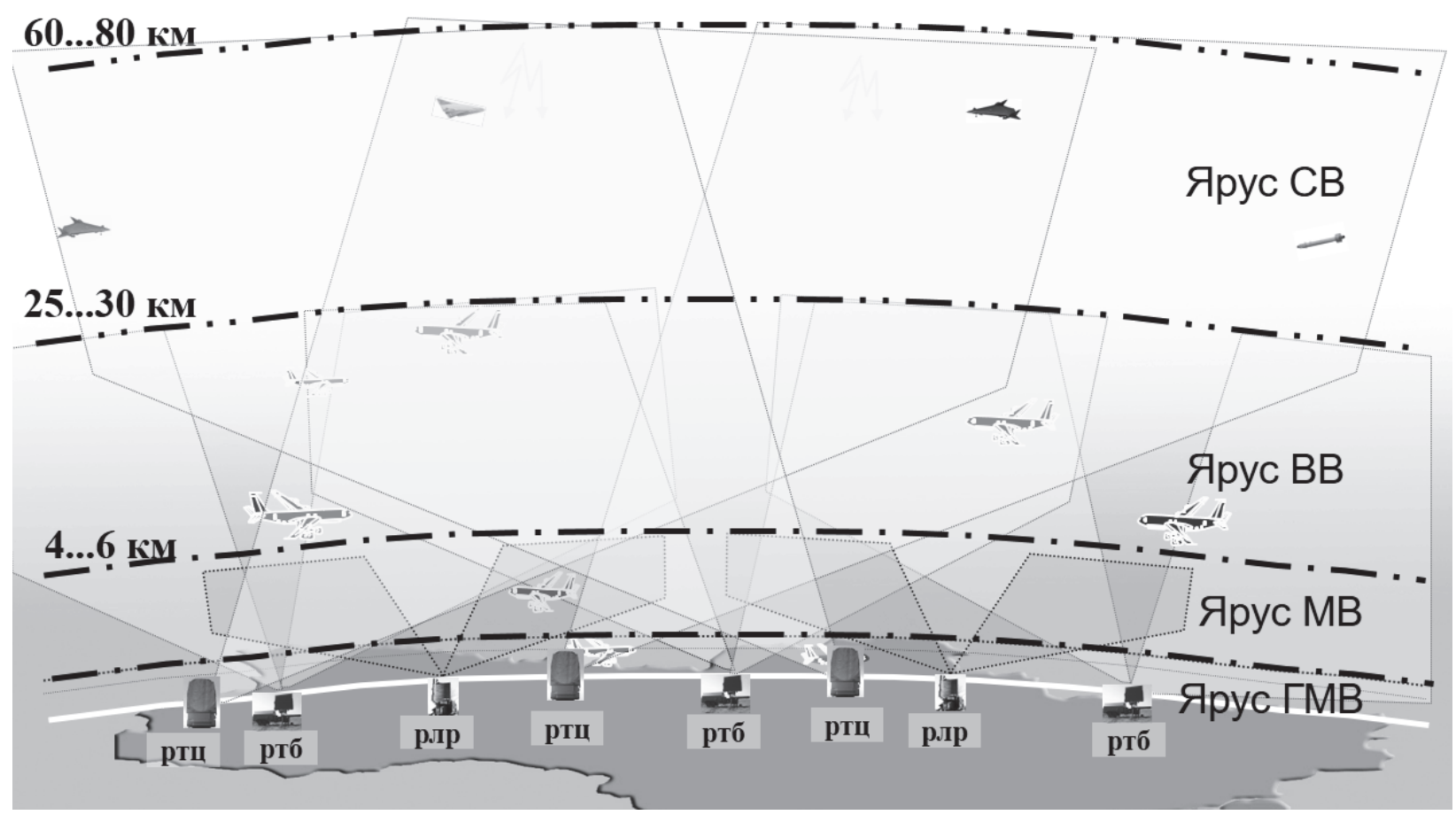

Рис. 5. Чотириярусна структура побудови радіолокаційного поля Джерело: розроблено авторами.

Запропонована чотириярусна побудова РЛП забезпечить нарощення спроможностей РТВ з виявлення та супроводження перспективних ЗПН без суттєвих структурних змін усієї системи радіолокаційної розвідки.

\section{Висновки}

1. Поява на озброєнні армій провідних країн світу таких специфічних ЗПН, як БпЛА та ГЗЛА, досить гостро поставила перед РТВ питання щодо нарощування спроможностей зі своєчасного виявлення та неперервного супроводження означених типів ЗПН та визначення шляхів і напрямків розвитку радіолокаційної системи у відповідності з новими викликами.

2. Існуюча система радіолокаційної розвідки здатна виявляти стратегічні та оперативно-тактичні БпЛА в межах тактико-технічних характеристик оглядових РЛС щодо виявлення пілотованих апаратів аналогічного призначення. Використання оглядових РЛС РТВ для виявлення тактичних міні-БпЛА $\epsilon$ недоцільним і невиправданим. Недоцільним - через надзвичайно низькі можливості 3 виявлення означеного типу цілей, а невиправданим - через невідповідність масштабів задач, для вирішення яких розроблялись РЛС РТВ, і задач $з$ виявлення мініБПЛА.
3. Для своєчасного виявлення і неперервного супроводження міні-БПЛА потрібні спеціалізовані РЛС 3 дальністю виявлення не більше 40 км, ефективною системою СРЦ по малошвидкісним цілям, що обумовлює необхідність використання в РЛС високої частоти посилок зондувальних сигналів. За допомогою подібних засобів можливо оперативно створювати осередкові РЛП до висот $300 \ldots 500$ м 3 метою виявлення міні-БПЛА в районах розташування ВДО та особливих зонах.

4. Існуюча радіолокаційна система неспроможна виявляти і супроводжувати перспективні ГЗЛА, оскільки область їхньої дії виходить за межі дії існуючої радіолокаційної системи за висотним і за швидкісним параметрами. Необхідними і невідкладними заходами мають стати розроблення і прийняття на озброєння спеціалізованих РЛС, здатних виявляти ГЗЛА типу ГЗКР на дальностях близько 1000 км і на висотах близько $60 . .80$ км.

5. Набуття РТВ спроможностей зі своєчасного виявлення і неперервного супроводження таких перспективних ЗПН, як міні-БПЛА і ГЗКР, можливе через перехід від двоярусної до чотириярусної побудови РЛП з чітким поділом відповідальності суб'єктів добування інформації про повітряну обстановку. 


\section{Список літератури}

1. Доктрина з охорони повітряного простору та протиповітряного прикриття важливих державних і військових об'єктів. Київ, 2020. 32 с.

2. Шамко В. Є., Жарик О.М., Коваль В.В. Розвиток форм і способів застосування Повітряних Сил Збройних Сил України в сучасних умовах ведення збройної боротьби. Наука і техніка Повітряних Сил Збройних Сил Украӥни. 2018. № 2(31). C. 9-15. https://doi.org/10.30748/nitps.2018.31.01.

3. Дудуш А. С., Тютюнник В. О., Резніченко О. А., Гогоянц С. Ю. Сучасний стан та проблеми протидії маловисотним, низькошвидкісним та малорозмірним БПЛА. Сучасні інформаційні технології у сфері безпеки та оборони. 2018. № 1(31). С. 121-131. https://doi.org/10.33099/2311-7249/2018-31-1-121-131.

4. Ярош С. П. Аналіз можливостей російського гіперзвукового авіаційного ракетного комплексу Х-47М2 "Кинжал”. Наука $i$ техніка Повітряних Сил Збройних Сил Украӥни. $2019 . \quad$ № $3(36)$. С. 79-85. https://doi.org/10.30748/nitps.2019.36.09.

5. Кондратюк Е. Исследования, проводимые в США в области создания гиперзвуковых летательных аппаратов. Зарубежное военное обозрение. 2013. № 2. С. 63-69.

6. Schwartz Mark R. Airland Battle Doctrine. Modern war. Jul-Aug 2013. No. 6. P. 28-31.

7. Харченко О. В., Кулєшин В. В., Коцуренко Ю. В. Класифікація та тенденції створення безпілотних літальних апаратів військового призначення. Наука і оборона. 2005. № 1. С. 47-54.

8. Рябуха В. П. Радиолокационное наблюдение беспилотных летательных аппаратов. Известия высших учебных заведений. Радиоэлектроника. 2020. Т. 63. № 11. С. 655-669. https://doi.org/10.20535/S0021347020110011.

9. Moses A., Rutherford M., Valavanis K. Radar-based detection and identification for miniature air vehicles. IEEE International Conference on Control Applications. Denver, CO, USA. September 28-30, 2011. P. 933-940. https://doi.org/ 10.1109/cca.2011.6044363.

10. Pham T., Srour N. TTCP AG-6: Acoustic detection and tracking of UAVs. U.S. Army Research Laboratory. Proc. of SPIE. 2004. Vol. 5417. P. 24-29.

11. Соловьев В. А., Купреев А. В., Жендарев М. В., Якименко И. В. Проблемы обнаружения беспилотных летательных аппаратов оптико-электронными устройствами. Электронный математический и медико-биологический журнал. 2011. Т. 10. Вып. 3. веб-сайт. URL: http://www.sci.rostelecom67.ru/user/sgma/MMORPH/N-31-html/solovjov/ solovjov.htm.

12. Даник Ю. Г., Бугайов М. В. Аналіз ефективності виявлення тактичних безпілотних літальних апаратів пасивними та активними засобами спостереження. Збірник наукових праць ЖВІ ДУТ. 2015. Вип. 10. С. 5-20.

13. Вишневський С. Д., Бейліс Л. В., Климченко В. Й. Потенційні можливості РЛС РТВ з виявлення оперативнотактичних та тактичних безпілотних літальних апаратів. Наука і техніка Повітряних Сил Збройних Сил Украӥни. 2017. № 2(27). C. 92-98. https://doi.org/10.30748/nitps.2017.27.18.

14. Лопин Г. А., Цурков М. Л., Оглоблин В. В. Угрожающая перспектива. Воздушно-космическая оборона. 2011. № 6. URL: http://www.vko.ru/koncepcii/ugrozhayushchaya-perspektiva.

15. Купцов И. М. Борьба с гиперзвуковыми летательными аппаратами: новая задача и требования к системе воздушно-космической обороны. Военная мысль. 2011. № 1. С. 10-17.

\section{Відомості про авторів:}

\section{Климченко Василь Йонович}

кандидат технічних наук доцент

провідний науковий співробітник

Харківського національного університету

Повітряних Сил ім. І. Кожедуба,

Харків, Україна

https://orcid.org/0000-0003-3999-8130

\author{
Дончак Дмитро Анатолійович \\ кандидат технічних наук \\ начальник відділу \\ Командування Повітряних Сил Збройних Сил України, \\ Вінниця, Україна \\ https://orcid.org/0000-0003-3301-7987
}

\author{
Донченко Михайло Миколайович \\ начальник управління \\ Командування Повітряних Сил Збройних Сил України, \\ Вінниця, Україна \\ https://orcid.org/0000-0003-0627-7943
}

\section{Information about the authors:}

\author{
Vasyl Klimchenko \\ Candidate of Technical Sciences \\ Associate Professor Lead Research \\ of Ivan Kozhedub Kharkiv \\ National Air Force University, \\ Kharkiv, Ukraine \\ https://orcid.org/0000-0003-3999-8130
}

\author{
Dmytro Donchak \\ Candidate of Technical Sciences \\ Chief of Department \\ of Air Force Command of Armed Forces of Ukraine, \\ Vynnytsya, Ukraine \\ https://orcid.org/0000-0003-3301-7987
}

\author{
Mykhailo Donchenko \\ Chief of Department \\ of Air Force Command of Armed Forces of Ukraine, \\ Vynnytsya, Ukraine \\ https://orcid.org/0000-0003-0627-7943
}


Тютюнник Владислав Олександрович кандидат технічних наук старший науковий співробітник начальник науково-дослідного відділу Харківського національного університету Повітряних Сил ім. І. Кожедуба, Харків, Україна https://orcid.org/0000-0002-7766-3246

\section{Vladyslav Tiutiunnyk}

Candidate of Technical Sciences Senior Research

Chief of Scientific Research Department

of Ivan Kozhedub Kharkiv

National Air Force University,

Kharkiv, Ukraine

https://orcid.org/0000-0002-7766-3246

\title{
ПРОБЛЕМЫ ПРИОБРЕТЕНИЯ СПОСОБНОСТЕЙ РАДИОТЕХНИЧЕСКИХ ВОЙСК ПО РАЗВЕДКЕ ПЕРСПЕКТИВНЫХ СРЕДСТВ ВОЗДУШНОГО НАПАДЕНИЯ
}

\author{
В.И. Климченко, Д.А. Дончак, М.М. Донченко, В.А. Тютюнник
}

Показано, что существуюшая система радиолокационной разведки воздушного пространства, физическую основу которой составляет двухъярусное радиолокачионное поле, не способна по объективным причинам осуществлять своевременное обнаружение и непрерывное сопровождение таких перспективных средств воздушного нападения, как малоразмерные беспилотные летательные аппараты тактического назначения и гиперзвуковые крылатые ракеты.

Проанализированы особенности радиолокационной разведки малоразмерных беспилотных летательных аппаратов тактического назначения и гиперзвуковых крылатых ракет подразделениями радиотехнических войск.

Определены пути и направления приобретения способностей радиотехнических войск по своевременному обнаружению и непрерывному сопровождению определенных типов летательных аппаратов.

Ключевые слова: радиолокационное поле, малоразмерные беспилотные летательные аппараты тактического назначения, гиперзвуковые крылатые ракеты, обнаружение, сопровождение.

\section{THE PROBLEMS OF ACQUISITION OF POSSIBILITIES OF RADAR TROOPS FOR RECONNAISSANCE OF AIR ATTACK MEANS}

\section{Klimchenko, D. Donchak, M. Donchenko, V. Tiutiunnyk}

It is shown, that the existing radar system of reconnaissance of air space, physical basis of which is the two-tier radar field, is incapable for objective reasons to timely detect and tracking of such perspective air attack means, as a tactical mini unmanned aerial vehicle (UAV) and hypersonic cruise missiles.

Features of radar reconnaissance of small tactical UAV are analyzed. It is shown, that use of surveillance radars of radar troops to detect of tactical UAV are inadvisable and unjustified. It is inadvisable because there are extremely low detection capabilities of specified type of targets. It is unjustified because scales of tasks for the decision of which developed surveillance radars of radar troops are not corresponding of scales of tasks of detection of mini-UAV. To solve this task should develop of special short-range radars, which will have improved capability for detecting of slow targets on the background of reflections from the ground. It can will be achieving by means use of radar with high pulse repetition rate.

It is shown, that the existing radar system is incapable to timely detect and tracking of hypersonic cruise missiles because the area of their action goes beyond limits of area of action of the existing radar system by altitude and speed parameters. It is proposed to develop and adopt special radars, which can detect of hypersonic cruise missiles on distance of about $1000 \mathrm{~km}$ and on altitude about $60 \ldots 80 \mathrm{~km}$.

The ways and directions of acquisition of possibilities of radar troops for timely detection and stable tracking of the marked types of targets are determined. It is shown, that physical basis of novel radar system of reconnaissance of airspace should become four-tier radar field.

Keywords: radar field, small tactical unmanned aerial vehicle, hypersonic cruise missiles, detection, tracking. 